\title{
Enhancing Biology Students' Academic Achievement and Attitude Through Self-Regulated Learning Strategy in Senior Secondary Schools in Delta Central Senatorial District
}

\author{
Oyovwi Edarho Oghenevwede (Ph.D.)
}

\author{
Department of Science Education, \\ Faculty of Education,Delta State University, \\ P.M.B. 1, Abraka, Delta State, Nigeria
}

Doi: 10.36941/jesr-2019-0017

\begin{abstract}
This study focused on enhancing biology students' achievement and attitude through Self-Regulated Learning Strategy in secondary schools in Delta Central Senatorial District. The study adopted the quasi-experimental pre-test, post-test control group design. Four research questions and four research hypotheses were formulated and raised to guide the study. The population of the study was all the biology students in senior secondary school II (SS II) in all the government-owned public secondary schools in Delta Central Senatorial District with an estimation of six thousand, four hundred and twentyone students (6,421). A sample of two hundred and forty-five (245) senior secondary schools II students randomly selected from four (4) public mixed secondary schools was used for the study. The Simple Random Sampling Technique was adopted to draw the sample. The instruments used for data collection were the Biology Achievement Test (BAT) and Biology Attitude Questionnaire (BAQ). BAT and BAQ were validated by I Measurement and Evaluation and Biology teachers that have taught biology for more than ten (10) years. The reliability of BAT and BAQ were established using Kuder-Richardson formula 21 and Cronbach Alpha which yielded a coefficient of internal consistencies of 0.75 for BAT and 0.80 for $B A Q$ respectively. Data were collected by administering the biology achievement test (BAT) and biology attitude questionnaire (BAQ) as pre-test and post-test. The data obtained were analysed using mean, standard deviation Analysis of Variation (ANOVA) and Analysis of Covariance (ANCOVA). The result shows that self-regulated regulated learning strategy significantly enhanced students' achievement in biology compared to the lecture method; there was no significant difference between the mean achievement score of male and female students taught biology using self-regulated learning strategy; there was a significant difference between the mean attitude score of students taught using selfregulated learning strategy compared with those taught with lecture method in favour of students taught using the self-regulated learning strategy and there was no significant difference between the mean attitude score of male and female students taught biology using self-regulated learning strategy. Based on the findings it was concluded that self-regulated learning strategy significantly enhances students' achievements and attitudes in biology. It was therefore recommended that biology teachers should adopt the strategy in teaching biology at the secondary school level and that biology teachers should be trained on how to use the skills of self-regulated learning strategy effectively.
\end{abstract}

Keywords: Self-Regulated; Strategy; Attitude; Achievement

\section{Introduction}

The industrial and technological development of any nation depends to a large extent on the level of scientific education of her citizens. The central purpose of science learning is conceptualized as developing scientific literacy in students (Dani 2009). The role of science in the development of any nation cannot be overemphasized since the level of scientific attainment of a nation has always 
been a very important index for measuring its level of development. This, in turn, determined the country's level of socio-economic as well as industrial development. One of the major subject areas necessary for such advancement in biology.

Biology is a branch of science structured to equip students with the knowledge of relevant concepts and scientific skills (Onyegegbu, 2002). It also aimed at developing broadly applicable skills such as problem-solving, communication, critical thinking and objective reasoning abilities to enable students to prepare for the workplace a self-sustainability in the world economy (Federal Ministry of Education FME, 2008). With this objective of the curriculum, students are expected to be useful and productive members of society. In order to achieve these objectives of biology, the teaching approach should promote students to assume responsibility and control over their acquisition of knowledge and skills. Thus students should become masters of their learning thereby controlling what, how, why and when they learn.

Self-regulated learning strategy is an active constructive process whereby learners set goals for their learning and attempt to monitor, regulate and control their cognition, motivation and contextual features in an environment (Tang 2012). It is an act of learning that is guided by metacognition (thinking about one's thought), strategic action (planning, monitoring and evaluating personal progress against standards) and motivation to learn to make the process of control and to evaluate one's own learning and behaviour. Unfortunately, these expectations tend to fall short which is attributed to a teacher who emphasizes theoretical presentation of biological concepts at the expense of the practical aspects which are weightier and more rewarding (Nwagbo, 2007). Perhaps, the lecture method of teaching commonly used by most biology teachers does not offer the students the opportunity for active participation and does not promote meaningful learning of biology concepts. It is hoped that making students take responsibility for their own learning through a self-regulated learning strategy may enhance students' academic achievement in biology. This study is therefore directed towards determining the effects of self-regulated learning strategy on biology students' achievements and attitudes in senior secondary school.

Good and Brophy (1995) defined self-regulated learning strategy as skills through which learner participate in the process of active learning and take responsibility for encouraging themselves to understand materials they deal with, to accomplish tasks, to monitor what they do to assess their strengths and weaknesses, and to take corrective action based on self-regulation reports.

To promote self-regulated learning strategy in the classrooms the teacher must teach students the self-regulated processes that facilitate learning. This process includes goal setting, planning, self-motivation, attention, control, self-monitoring, self-evaluation, appropriate help-seeking and flexible use of learning strategies.

Studies have revealed that self-regulated learning strategy has positively improved students' achievements in various subject areas (Gerard, Annemaree \& Nan 2013, Hamid Zahra \& Seyed, 2015; Zimmerman, 2002). This is because it gives students an explicit plan for improving upon their achievements in science subjects and also helps them to understand the relationship between knowledge, skill, and motivation. The evidence from the reviewed literature is not conclusive, however, there are also little or no studies on the effects of self-regulated learning strategy on students' achievement and attitude in senior secondary schools in Delta Central Senatorial District. Since most of the studies were conducted using higher institutions and in other subject areas. Therefore, it is imperative to carry further studies to provide more empirical evidence on the effect of self-regulated learning on student achievement and attitude towards biology.

Hattie (2009) defined achievement as the performance outcomes that indicate the extent to which a learner has accomplished specific goals that were the focus of activities in instructional environments especially in colleges and universities. Othman, Semarack, and Leng (2011) defined achievement as the extent to which a learner is profiting from instruction in a given area of learning. Academic achievement is the outcome of learning which expresses the extent to which instructional objectives have been met. Thus academic achievement can be viewed as the knowledge attained and skill developed in school subjects, the level of what is determined by test scores. The use of self-regulated learning strategy not only improve student academic achievement but also improve students attitude. 
According to Eagly and Chiaken (2007), attitude is a psychological tendency that is expressed by evaluating a particular entity with some degree of favour or disfavour. Attitude is the opinion and feeling that you usually have about something. Studies have shown that self-regulated learning strategy improve students' attitude towards science subjects (Arsal, 2019; Ozdemir \& Arslan, 2016; Zumbrune, 2010).

\section{Research Questions}

1. Is there any difference between the mean achievement scores of students taught biology using a self-regulated learning strategy and those taught using the lecture method?

2. Is there any difference between the mean scores of male and female students taught biology using a self-regulated learning strategy?

3. Is there any difference between the mean attitude scores of students taught biology using a self-regulated learning strategy and those taught using the lecture method?

4. Is there any difference between the mean attitude scores of male and female students taught biology using a self-regulated learning strategy?

\section{Research Hypothesis}

The following hypothesis raised from the research questions were tasted at 0.05 level of significance:

1. There is no significant difference between the mean achievement scores of students taught biology using a self-regulated learning strategy and those taught using the lecture method.

2. There is no significant difference between the mean achievement scores of male and female students taught biology using a self-regulated learning strategy.

3. There is no significant difference between the mean attitude scores of male and female students taught biology using a self-regulated learning strategy and those taught using the lecture method.

4. There is no significant difference between the mean attitude scores of male and female students taught biology using the self-regulated learning strategy.

\section{Purpose Of The Study}

The purpose of the study is on enhancing biology students' effect of self-regulated learning strategy on students' achievement and attitude in biology.

Specifically, the study seeks to determine:

i. If there is a difference between the mean achievement scores between students taught biology using self-regulated learning strategy and those taught using the lecture method.

ii. If there is a difference in the mean achievement scores of male and female students taught biology using a self-regulated learning strategy.

iii. If there is a difference in the mean attitude scores of students taught biology using selfregulated learning strategy and those taught using the lecture method.

iv. If there is a difference in the mean attitude scores of male and female students taught using a self-regulated learning strategy.

\section{Methodology}

The study focused on enhancing biology students' academic achievement and attitude through selfregulated learning strategy in senior secondary schools in Delta Central Senatorial District. The study adopted the quasi-experimental pre-test, post-test, and control group design. Four research questions and four research hypotheses guided the study. The population of the study was all the biology students in senior secondary schools in Delta Central Senatorial District with an estimation of six thousand, four hundred and twenty-one students $(6,421)$. A sample of two hundred and forty- 
five (245) senior secondary school two (SSII) students randomly selected from four (4) public mixed secondary schools was used for the study. The simple random sampling technique was adopted to draw the sample. The instruments used for data collection were Biology Achievement Test (BAT) and Biology Attitude Questionnaire (BAQ). BAT and BAQ were validated by experts in Measurement and Evaluation and biology teachers that have taught biology for more than ten (10) year.

The instruments were trial-tested with the help of two research assistants on a sample of 150 students outside the sampled areas in Ekiugbo secondary school Ekiugbo Ughelli to establish the reliability. Using Kudar-Richardson formula 21 and Cronbach Alpha, a coefficient of internal consistency of 0.74 for BAT and 0.80 for BAQ were obtained respectively BAT consisted of 30 multiple choice test items constructed from the instructional units. BAQ consists of 25 items seeking respondents' (students) opinion on the effects of self-regulated learning on student's attitudes towards biology. The responses were framed on a 4-Point-Likert scale of strongly agree (SA-4); Agree (A-3); Disagree (D-2) and Strongly Disagree (SD-1).

The students were randomly assigned to a self-regulated learning strategy group (experimental) and lecturer group (control). Four intact SSII classes from the four schools selected for the study were randomly selected to make up the experimental and control group respectively. Both the experimental and control groups were exposed to the same biology subject matter and learning environment. The experimental groups were taught using a self-regulated learning strategy while the control group was taught with the lecture method. Four teachers in the four selected schools were used as research assistants. They were trained on the skills of using the selfregulated strategy and lecture method respectively.

The treatment lasted for a period of 4 weeks, before the commencement of treatment, both the experimental and control groups were pre-tested with Biology Achievement Test (BAT) and Biology Attitude Questionnaire (BAQ). This was done to determine the equivalence of the group. After this, the treatment was done by exposing the students in the experimental group to a selfregulated learning strategy while the control group was exposed to the lecture method. Toward the end of the treatment, students in both the experimental and control group were post-tested with the BAT and BAQ after re-shuffling the items and scored accordingly. The data obtained were analysed using mean, standard deviation, Analysis of Variance (ANOVA) and Analysis of Covariance (ANCOVA).

\section{Result}

The result of this study was presented in line with the research questions and the hypotheses as follows.

Table 1: Mean and standard deviation of pre-test and post-test achievement scores between students taught Biology using self-regulated learning strategy and lecture method

\begin{tabular}{|l|c|c|c|c|c|c|}
\hline Group & $\mathrm{N}$ & Pre-test Mean & SD & Post-test Mean & SD & Mean gain \\
\hline Self-regulated strategy & 124 & 28.36 & 6.40 & 52.21 & 11.511 & 29.21 \\
\hline Lecture & 121 & 28.42 & 7.20 & 46.42 & 9.86 & 20.42 \\
\hline
\end{tabular}

Table 1 shows a mean achievement pre-test score of 28.36, with a standard deviation of 6.40 for students taught biology with self-regulated strategy while those taught with lecture method had a mean achievement score of 28.42 with a standard deviation of 7.20 . As for the post-test, students taught biology using a self-regulated learning strategy had a mean achievement score of 52.21 and a standard deviation of 11.50 while their counterparts taught with lecture method had a mean score of 46.42 with a standard deviation of 9.86 . From the table, students in the self-regulated learning strategy had a higher mean gain of 29.21 while their counterparts in the lecture group had a mean gain of 20.42 . 
Table 2: ANOVA comparison of post-test achievement score of students taught biology using selfregulated learning strategy and lecture method.

\begin{tabular}{|l|c|c|c|c|c|}
\hline & Sum of squares & df & Mean square & $\mathrm{F}$ & sig \\
\hline Between groups & 6351.334 & 1 & 6351.334 & 52.310 & .000 \\
\hline Within groups & 22416.984 & 250 & 139.194 & & \\
\hline Total & 34029.117 & 251 & & & \\
\hline
\end{tabular}

Table 2 shows that there is a significant difference between the mean achievement post-test score of students taught biology using a self-regulated learning strategy and those taught using a lecture method in favour of students taught using a self-regulated learning strategy.

Table 3: Mean and standard deviation of pre-test and post-test achievement score of male and female students taught biology using self-regulated learning strategy.

\begin{tabular}{|l|c|c|c|c|c|c|}
\hline Sex & $\mathrm{N}$ & Pre-test & & Post-test & & Mean gain \\
\hline & & Mean & SD & Mean & SD & \\
\hline Male & 60 & 30.60 & 5.60 & 59.50 & 12.51 & 27.82 \\
\hline Female & 64 & 27.42 & 6.84 & 59.61 & 12.65 & 30.42 \\
\hline
\end{tabular}

Table 3 shows a mean achievement pre-test score of 30.61 with a standard deviation of 5.60 for male students taught biology using a self-regulated learning strategy, while the female had 27.42 mean achievement scores with a standard deviation of 6.84. As for the post-test, male students had 59.50 mean achievement scores with a standard deviation of 12.51 while the female had a mean achievement score of 59.61 with a standard deviation of 12.65. The female students had a higher mean achievement gain of 30.42 compared to their male counterparts which had a mean achievement of 27.82 .

Table 4: ANOVA comparison of post-test achievement score of male and female students taught biology using self-regulated learning strategy.

\begin{tabular}{|l|c|c|c|c|c|}
\hline Source & Type III sum of square & df & Mean square & F & Sig \\
\hline Corrected model & 66.121 & 2 & 34.065 & .211 & 810 \\
\hline Intercept & 21127.762 & 1 & 21127.762 & 136.879 & .000 \\
\hline Pre & 65.244 & 1 & 65.244 & .416 & .000 \\
\hline Sex & 317 & 1 & .317 & .003 & .960 \\
\hline Error & 20223.369 & 125 & 151.624 & & \\
\hline Total & 36604.000 & 127 & & & \\
\hline Corrected total & 20291.500 & 127 & & & \\
\hline
\end{tabular}

From the table, a non-significant difference was found between the mean achievement post-test score of male and female students taught biology using self-regulated learning strategy.

Table 5: Mean and standard deviation of pre-test and post-test altitude score between students taught biology using self-regulated learning strategy and lecture method.

\begin{tabular}{|l|c|c|c|c|c|c|}
\hline Group & $\mathrm{N}$ & Pre-test & & Post-test & & Mean gain \\
\hline & & Mean & SD & Mean & SD & \\
\hline Self-Regulated Strategy & 124 & 21.21 & 8.20 & 52.42 & 6.20 & 32.12 \\
\hline Lecture & 121 & 20.40 & 8.55 & 50.14 & 8.14 & 30.17 \\
\hline
\end{tabular}

Table 5 shows a mean attitude pre-test score of 21.21 with a standard deviation of 8.20 for students taught biology using a self-regulated learning strategy. While students taught with lecture method had a mean attitude pre-test score of 20.40 with a standard deviation of 8.55 . As for the post-test score, students taught with a self-regulated learning strategy had a mean attitude score of 52.42 
with a standard deviation of 6.20 while their counterparts taught using lecture method had a mean score of 50.14 with a standard deviation of 5.19. Students in the self-regulated learning strategy had a higher mean attitude gain of 32.12 compared to their counterparts in the lecture group which had a mean attitude gain of 30.17 .

Table 6: ANOVA comparison of post-test attitude score of students taught biology using selfregulated learning strategy and lecture method.

\begin{tabular}{|l|c|c|c|c|c|}
\hline & Sum of square & df & Mean square & F & Sig \\
\hline Between group & 315.461 & 1 & 315.461 & 3.460 & .035 \\
\hline Within group & 15217.424 & 250 & 63.725 & & \\
\hline Total & 17075.271 & 251 & & & \\
\hline
\end{tabular}

Table 6 shows a significant difference between the mean attitude post-test score of students taught biology using self-regulated learning strategy and those taught with the use of lecture method in favour of students taught with the use of lecture method in favour of students taught using selfregulated learning strategy.

Table 7: Mean and standard deviation of pre-test and post-test attitude score of male and female students taught biology using self-regulated learning strategy

\begin{tabular}{|l|c|c|c|c|c|c|}
\hline Sex & $\mathrm{N}$ & Pre-test & & Post-test & & Mean gain \\
\hline & & Mean & SD & Mean & SD & \\
\hline Male & 60 & 22.64 & 7.24 & 55.26 & 6.20 & 33.25 \\
\hline Female & 64 & 20.25 & 9.21 & 54.20 & 6.11 & 34.31 \\
\hline
\end{tabular}

Table 7 shows a mean attitude pre-test score of 22.64 with a standard deviation of 7.24 for male students taught biology using self-regulated learning strategy while the female counterparts had a mean attitude score of 20.25 with a standard deviation of 9.21. As for the post-test, the male students had a mean attitude score of 55.26 with a standard deviation of 6.20 while the female had a mean attitude score of 54.20 with a standard deviation of 6.11 . The female students in the selfregulated learning group had a slightly higher mean attitude gain of 34.31 compared to their counterparts which had a mean attitude gain of 33.25 .

Table 8: ANOVA comparison of post-test attitude score of male and female students taught biology using self-regulated learning strategy.

\begin{tabular}{|l|c|c|c|c|c|}
\hline & Sum of squares & $\mathrm{df}$ & Mean square & $\mathrm{F}$ & Sig \\
\hline Between group & 2.267 & 1 & 2.267 & .045 & .832 \\
\hline Within group & 5617.129 & 126 & 50.291 & & \\
\hline Total & 5617.129 & 127 & & & \\
\hline
\end{tabular}

Table 8 shows a non-significant difference between the mean attitude post-test score of male and female students taught biology using a self-regulated learning strategy.

\section{Discussion of Results}

The result of this study has indicated that there is a significant difference between the mean achievement scores of students taught biology using a self-regulated learning strategy and those taught using a lecture method in favour of students taught using a self-regulated learning strategy. The finding was in agreement with Olakanmi and Gumbo (2017) who reported that self-regulated learning significantly improved student achievement. This was also in line with Orue and Arslan (2016) who reported that self-regulated learning strategy significantly increases the metacognitive thinking skills and achievement of students. This positive outcome in favour of self-regulated 
learning strategy was the fact that the strategy has the capacity to arouse and sustain students' motivation and interest as well as helping students to develop learning skills.

The study also showed a non-significant difference between the mean achievement scores of male and female students taught biology using a self-regulated learning strategy. This indicates that the strategy is not gender bias, which was in conformity with Yukselturk and Bulut (2009). However, there are contradictions with views of Anyichie and Onyedike (2002) who reported that males performed significantly better than their female counterparts.

Another finding revealed that there is a significant difference between the mean attitude score of students taught biology using self-regulated learning strategy and those taught using the lecture method in favour of students taught using the self-regulated learning strategy. These findings are in agreement with Ozdemir and Arslan (2016) who reported that self-regulated learning strategy significantly enhances students attitude which was contested by Orue and Arslan (2016) who reported that there was no significant difference between the mean attitude scores of students taught using self-regulated learning strategy and lecture method.

The study finally showed a non-significant difference between the mean achievement score of male and female students taught biology using a self-regulated learning strategy. This was in agreement with Garmabi and Zarein (2016) and Rahman (2011) who reported a non-significant difference in the attitude score of male and female students taught biology using a self-regulated learning strategy.

\section{Conclusion}

Based on the discussion and findings of the study, it can be concluded that a self-regulated learning strategy significantly improves students' achievements in biology compared to the lecture method as well as enhancing students' attitudes towards biology. There is, therefore, the need to acknowledge that self-regulated learning strategy plays a significant role in the study of biology. And should be adopted. Biology teachers, therefore, need to be groomed on the requisite skills needed for effective implementation.

\section{Recommendations}

1. Biology teachers should adopt the self-regulated learning strategy in teaching biology at the secondary school level

2. Biology teachers should be trained on how to effectively use self-regulated learning strategy skills and also to acquaint them with the importance of the strategy.

3. The government should provide an enriched learning environment in schools to facilitate the use of the strategy.

\section{Reference}

Anyichie, A.C \& Onyedike, C.C. (2012). Effects of self-regulated learning strategy on secondary school's students' academic achievements in solving mathematical world problems in Nigeria. International multidisciplinary Journal, Ethiope 6(4), 302-323

Arsal, Z (2009). The impact of self-regulated instruction on mathematics achievements and attitudes of elementary school students. Egitim ve Rilim 34(3.14)

Dani, D. (2009) Scientific literacy and purposes for science. A case study of Lebanese private school teachers. International Journal of Environmental and science education, 4(3), 289-299

Della, S (2008). Longman dictionary of contemporary English. Edinburgh Gate Harlow Essex, England: Pearson Education limited.

Eagly, A.H, \& Chaiken S (2007). The advantages of an inclusive definition of attitude. Social Cognition, 25(5), $582-602$

Federal Ministry of Education (FME), (2008). National Curriculum for science secondary school biology. Lagos: Government press

Gamabi, H \& Zarein, G. (2016). EPL teachers' attitude towards the effectiveness of metacognitive strategies used by high school students. International Journal of Learning and Development, 6(1), 61-75 
Gerad, E, Annemaree, C \& Nan, B (2013). Self-regulated learning. Key skills and their sources in a sample of adolescent males. Australian Journal of Educational \& developmental biology, 13 (1), 58-74

Good, T, \& Brophy, J. (1995). Continued educational psychology, U.S.A: Longman.

Hamid, R.R Zahra, V, Seyed, H (2015). Studying the relationship between self- regulation and high school students academic motivation of the second course in county of Larestan. Indian Journal of fundamental and Applied life science, 5(51), 455-467

Hattie, J. (2009). Visible learning. Hattie rankings: 195 influences and effects sizes related to students achievement, University of South Australia, ACER

Lang, E.L (2012). Self-regulated learning between low, average, and high-math achievers among pre-university international students in Malaysia. European Journal of social sciences, 30(2), 302-312

Nwagbo, C.R (2007) Developing observational and Drawing skills in teachers for effective conduct of practicals. STAN National Biology panel workshop series Jos, Plateau state.

Nwanze, A.C. (2016). Effect of multimedia synchronized instructional strategy on students' achievement and retention in secondary school chemistry in Onitsha education zone. Unpublished M.Ed Dissertation submitted to the department of science education, Nnamdi Azikiwe University Awka.

Olakanmi, E.E \& Gumbu, M.T. (2017). The effect of self-regulated learning training on students. Meta-cognitive and achievement in chemistry. Open Journal Systems 25(2), 161-170.

Onyegegbu, N. (2002). Provision of facilities in biology classroom: New direction and challenges, Journal of Education Research 4, 70-75

Orue, A, \& Arslan, A. (2016). The impact of self-regulated learning on reading comprehension and attitude towards Turkish course and meta-cognitive thinking. Educational Researches and Reviews, 11(8), 523529

Othman, N, Semarak, J, Leng K.B (2011). The relationship between self-concept, intrinsic motivation, selfdetermination and academic achievement among Chinese primary school students. International Journal of Psychological studies, 3(1), 90-98

Ozdemir, E, \& Arslan, A (2016). The effect of self-regulated Jigsaw iv on university students' academic achievements and attitudes towards English course. Journal of Education and Training Studies 4(5), 3843

Rahman, F. (2011). Effects of some students related factors on their metacognitive awareness Language of India,11(4),76-85.

Yukselturk, E, \& Bulut, S. (2009). Gender differences in self-regulated online learning environment. Educational Technology and Society 12(3), 12-22

Zimmerman, B.J (2001). Theories of self-regulated learning and academic achievement. And overview and analysis in B.J. Zimmerman \& D.H. Shunk (eds) self-regulated learning and academic achievement: Theoretical perspectives ( $2^{\text {nd }}$ ed, pp:1-37). Mahwah, N.J. Erlbaum.

Zimmerman, B.J. (2002). Becoming a self-regulated learner: An overview. Theory into practice 41(2), 64-72

Zumbrunn, S. (2010). Nurturing young students' writing knowledge, self-regulation, attitudes and self-efficiency. The effect of self-regulated strategy development. Public access theses and dissertations from the College of Education and Human Sciences 71 